\title{
Modern Things on Trial: Islam's Global and Material Reformation in the Age of Rida, 1865-1935
}

\author{
Leor Halevi \\ New York: Columbia University Press, 2019. 378 pages.
}

The late writer and intellectual George Tarābīshī (d. 1437/2016) observes that when the tomato first made its appearance in late nineteenth century Aleppo, locals took to denouncing it as 'the Devil's arse' (mu'akhirat al-shaytān) on account of its colour. The muftì of the city, who remains curiously unnamed in this account, is said to have issued a fatwa on its prohibition. ${ }^{1}$ Unsurprisingly, no source is given for this anecdote, but the point is clear enough: jurists are hidebound creatures, wrong-footed by the advent of modernity and stupid or morally depraved, or perhaps both. One could give many other examples that serve to illustrate the same conclusion. Leor Halevi's formidable monograph on the fatāwā of Rashīd Ridā (d. 1354/1935) in al-Manār is thus precisely what one would hope for in the study of this much maligned Islamic legal instrument. ${ }^{2}$ The author is meticulous in contextualising Ridāss interventions across a range of controversial issues relating to modern objects and technologies, from toilet paper to the telegraph. His use of sources is most impressive, going far beyond what one has come to expect of intellectual histories produced in the tradition of Islamic studies. Along with the ubiquitous fatwa collections, he deploys everything from shipping records to department store catalogues to properly situate the material transformation of the Muslim world. Halevi's approach is framed as revisionist, redressing the longstanding neglect of materiality in the discipline (9-10) while emphasizing the 'ground-up' nature of Islamic law. The jurist's verdict is seen to lie at the end of a long causal chain, preceded by the new object itself and the discussion it elicits upon first contact (28-29). Even the istifta $\bar{a}$ soliciting an opinion is often shaped in such a way as to direct the respondent towards particular legal outcomes, Halevi demonstrates; the mustaft $i$ is not infrequently invested in one or another perspective (e.g. 189-190). Halevi also makes a signal contribution to the study of the Afghānī-'Abduh-Riḍa triumvirate and their relationship(s) to modern Salafism. He roundly endorses Lauzière's contentions about the historical use of this term, highlighting Riḍās departures from his Egyptian mentor (124-125) while pushing back against claims that serious discontinuities are evident in the course of his career (244-245). These are all 
soundly argued. It is unfortunate that the author does not draw on Brown's fourfold typology in explicating these differences of opinion. ${ }^{3}$ Riḍās wellknown collaboration with Ibn Sa ùd (d. 1373/1953), moreover, while to no small extent explained by the latter's need for legitimation and assistance in printing Wahhābī works, owes much to genuine theological alignments, a point that deserves greater emphasis. ${ }^{4}$ It is no coincidence that Riḍa shared many enemies with Wahhābi 'ulamā' in the early twentieth century: the nature of these sympathies is clear from such episodes as Ridā's defence of 'Abd Allāh al-Qașīmī (d. 1416/1996) against the Late Sunni Traditionalist Yūsuf al-Dijwī (d. 1365/1946). ${ }^{5}$

The introductory chapter of the book outlines and justifies Halevi's theoretical interventions. His subsequent focus is mostly on a set of discrete cases of modern objects addressed in the pages of al-Manār. The second chapter presents a detailed and extremely useful survey of the dynamics of the journal's circulation, including a map (58) and a periodization $(57,59-$ 61) of the geographic origins of its istifta'a $a$ t, which shifted noticeably over time. Halevi questions Goldziher's absurd claim that these were the product of Ridâas fertile imagination (275n60). He illustrates the entanglements of al-Manār with the material facts of 'the first globalization' (c. 1870s-1918), the boom in trans-global trade and commerce whose impress is everywhere felt in its accommodating fatāwa (253). This world-one not of Islamdom's own making-is firmly located as the one into which Ridā was born. The impacts of these globe-spanning changes were very much present in (Lebanese) Tripoli, where he received his formative religious education under the tutelage of Husayn al-Jisr (d. 1327/1909). Halevi invokes the notion of 'Laissez-faire Salafism' throughout to frame Ridā's justification of the resort to various modern means to facilitate Muslim 'flourishing' (e.g., 265). This commitment produced some irregular opinions, sanctioning for instance the purchase of lottery tickets in Buddhist Bangkok (231-232) and the sale of wine in French Mandate Lebanon (239-240), moves defended by appealing to the premodern territorial designation dār al-harb. The author is basically correct in stating that the juristic tradition can be wielded to defend a variety of mutually exclusive legal views (including the sale of alcohol, 263). Insufficient attention, however, is paid to the manner in which these appeals often subvert the logic of their original sources, even though Halevi is clearly aware of the radically transformed contexts of modern and premodern juristic activity (26-27). These differences are only partly explained by such factors as school loyalties, accessibility of style, and so on. ${ }^{6}$ 
Halevi notes that only a small number of modern objects provoked legal controversy; these mostly relate to commercial instruments, purity concerns, and articles of dress (262-264). There was no inevitability in this conflict: only the relatively few material things freighted with symbolic power merited sustained attention from jurists, and these gave rise to differing points of view. These objects are conceptualized as 'Euro-Muslim' goods (15-16), integrating their materially European origins with their Islamic uses. Interestingly, Ridā only rarely employed the term 'Western' himself, preferring 'Frankish' or 'Frankization' (210). ${ }^{7}$ It is in his cataloguing of the debates about specific material objects that Halevi is arguably at his most brilliant; discussion of the receptions of toilet paper (chapter one), the gramophone (chapter five), and telegraphy and photography (chapter six) are richly illustrated (sometimes literally so) and extremely engaging. Music purists will be intrigued to learn that listening to shellac discs (common in the Arab world until the 1970s) was initially compared to 'eating with dentures' (132). Where relevant, Halevi shifts to expand on local debates (including Central, South, and Southeast Asian), exploring how al-Manār was often called upon to contribute to pre-existing controversies. These interventions yield occasional surprises; Riḍa is ambivalent about the playing of Qurānic records and criticises the Egyptian Mutịi îs opinion on the subject as too lenient (146), adding that the discs are subject to the same standards of treatment as the mushafitself (148). But in the great majority of cases, Riḍa plays the part expected of him, always with the aim of facilitating this-worldly prosperity (Halevi's translation of the Arabic yusr) for the global Muslim community $(25,43,100)$. This is his underlying aim throughout the fatāwa reviewed in the book: the hope that Muslims will come to occupy their place among modern peoples, as it were.

It is impossible to do justice to Halevi's Modern Things on Trial in so short a space, but one hopes this review has succeeded in conveying a sense of its impressive range, accessibility, and relevance. This is an outstanding work that sets a new standard for the writing of modern Islamic intellectual history-even as the author insists that his focus is very much on material things. Whether or not one agrees with his conclusion that "Islam's reformation...was a materialist movement rooted in modern objects" (262), the reader is left with a deftly contextualised series of studies of a number of significant legal debates. This book will prove of enduring interest to researchers in Islamic law and modern Islamic thought, historians of the late imperial and early nation-state Muslim worlds, and students of the processes of globalization more generally. 


\section{Endnotes}

1. Tarābīshī, Min al-Nahḍa ilā l-ridda: tamazzuqāt al-thaqāfa al-'́arabiyya fī 'asr al-'awlama (Beirut: Dār al-sāqī, 2000), 192. He notes that Aleppans still refer to the tomato as a 'franjiyya'. Damascenes prefer 'banadüra', a corruption of the Italian 'pomma dora'. I have not been able to find a source for the original story, despite extensive searching.

2. "Reactionary fatwas such as these could serve to tell sensational stories about the constraints that sacred law has placed on the consumption of strange new things.... Yet the sacred law is not a rigid ideological superstructure that has worked to restrict the free flow of goods" (25).

3. See Jonathan A.C. Brown, Hadith: Muhammad's Legacy in the Medieval and Modern World, 2nd ed. (Oxford: Oneworld, 2017), chapter ten. Halevi does contrast 'purist' and 'modernist' Salafism, echoing Brown's typology, but without referencing him. He remains unconvinced that this bifurcation is a meaningful one (244).

4. These are abundant in his notes on 'Abduh's Risālat al-Tawhìd. He is often at pains to correct his mentor's neglect of Taymiyyan theology while arguing (unpersuasively) that he was an adherent of the "way of the Salaf". For an example, on tawhīd al- 'ibāda, see Risālat al-Tawhìd, ed. Muhammad Rashìd Rị̣ā (Amman: al-Hay’a al-'āmma li-quṣūr al-thaqāfa, 2000), 5. His indebtedness to Wahhābī formulations of this doctrine is obvious.

5. For Ridāàs fulsome praise of Qașīmī’s Wahhābī polemic Kitāb al-Burūq al-najdiyya fī Iktisāḥ al-zulamāt al-Dijawiyya, see al-Manār, vol. XXXII, no. 4 (Dhū l-Hijja 1350/April 1932), 308-315. In his EI3 article "Atheism (modern)", Carool Kersten invariably gives his name as "Qāsimī", suggesting a lack of access to his writings.

6. Take the issue of the expulsion of non-Muslims from the jazirat/ard al-'arab, for example (240-242). Riḍās claim to agree with the Shäficite view on the issue ignores the radically different logic of premodern jurists, who justified the expulsion on completely different grounds, including the fear of non-Muslim treachery, the exaltation of Islam over other religions, protection of the sacred precinct from potential non-Muslim aggression etc. See Ibn Bațāal (d. 449/1057), Sharh Ṣaḥịh al-bukhārī, ed. Yāsir b. Ibrāhīm (Riyadh: Maktabat al-rushd, n.d.), 5:342-344. See also Shāh Walī Allāh (d. 1176/1762), Hujjat Allāh al-bāligha, ed. Sayyid Sābiq (Beirut: Dār al-jīl, 2005), 2:276.

7. The reviewer recalls being surprised in his childhood to hear bread rolls referred to in the local dialect as 'Frankish bread' (khibz franjī).

Omar Anchassi

Early Career Fellow in Islamic Studies University of Edinburgh, Edinburgh, UK 